\title{
Hilfe für Abgebrannte, ländliche Feste und medizinische Versorgung. Wohltätiges Engagement von Frauen
}

\begin{abstract}
Im I9. Jahrhundert wirkten stereotype, weibliche Rollenzuschreibungen wie die der Sorgenden, Fühlenden und zunehmend auch Religiösen für Frauen nicht nur einschränkend, sondern eröffneten unter Umständen Betätigungsfelder, die als speziell weibliche Wirkungsbereiche verstanden wurden. In diesem Beitrag, der sich mit weiblicher Wohltätigkeit als soziale Praxis auseinandersetzt, wird danach gefragt, inwiefern geschlechterspezifische Normen zur Ressource wurden, auf deren Grundlage Raum beansprucht und Expertise geäußert werden konnte. Dabei wird die I8Io gegründete Gesellschaft adeliger Frauen zur Beförderung des Guten und Nützlichen in den Blick genommen. Die „gute Sache“ bot speziell besitzenden Frauen die Möglichkeit, sich mit Spenden in das kollektive Gedächtnis eines Ortes oder einer Region einzuschreiben, öffentlich aufzutreten und Expertise für sich zu beanspruchen, zumeist in Zusammenarbeit mit dem Klerus. Obwohl die unpolitische Motivation stets unterstrichen wurde und werden musste, etablierten sich Frauen als keineswegs unpolitische Akteurinnen.
\end{abstract}

Support for Victims of Fire, Rural Festivities and Medical Care. Women's Charitable Engagement. Within the framework of $19^{\text {th }}$-century gendered stereotypes, women were understood to be caring, emotional and, increasingly, pious. The impact of such norms was not solely restrictive; rather, women also began to use them to enter fields of activity that were understood as specifically female. This chapter is concerned with female charity as a social practice and asks to what extent gender-specific norms were used as a resource and who claimed expertise on the matter. Thereby, the Society of Aristocratic Women to Promote the Good and the Useful founded in I8Io is taken into consideration. The "good deed" offered women the opportunity to inscribe themselves in the collective memory of a place or region, to appear in public and to claim expertise, mostly in cooperation with the clergy. Although the apolitical motivation of their activities was and always had to be emphasised, women established themselves as by no means apolitical actors.

Keywords: charitable associations, gendered norms, poor relief, health care, education

doi.org/10.52035/noil.2021.19jh02.14

Veröffentlicht nach externer Begutachtung (doppelblind) / published after external peer review (double blind) 